Steers, J. A., 1939. Sand and Shingle Formations in Cardigan Bay. Geogrl J., 94, 209-227.

\author{
Sand Movement Study Group, \\ C/O NATIONAL INSTITUTE OF ÓCEANOGRAPHY, \\ WORMLEY, \\ Godalming, Surrey. \\ 12th April, 1967.
}

Vivian N. D. Caston.

\title{
THE POSITION OF THE WENLOCK/LUDLOW BOUNDARY IN THE SILURIAN GRAPTOLITE SEQUENCE
}

SIR,-We are currently preparing a detailed account of the faunal stratigraphy of the Wenlock/Ludlow passage beds of Wenlock Edge and Hopedale, Shropshire. Our communication is prompted by the letter of Warren, Rickards, and Holland in this Magazine (1966, 103, p. 466-7). The comments of these authors pertinent to our study involve the assignment of the Wenlock Limestone to the graptolite zone of Pristiograptus ludensis (= vulgaris) and the reference of this zone to the Wenlockian.

We concede that the base of the Ludlovian Series as defined by Wood (1900, p. 422) at the base of the $P$. ludensis $(M$. vulgaris) zone is no longer tenable following the report by Warren, Rickards, and Holland that species indicative of this zone occur below and within the Wenlock Limestone of the Ludlow area. We fail, however, to agree with their statement (p. 467) that the base of the Ludlovian as currently defined at Ludlow by Holland, Lawson, and Walmsley (1963, p. 139) " would appear to lie more or less at the base of the Pristiograptus nilsonni zone". The Wenlock/Ludlow junction in fact occurs at the base of the "Barren " beds of Alexander (1936) (= Lower Elton Beds), from which graptolites have not yet been recorded at Ludlow.

In our study of the passage beds between the limestone facies of the Wenlock Limestone and the Lower Elton Beds of Wenlock Edge we have found no evidence to suggest that the latter beds (which are the direct correlatives of the lower Elton Beds at Ludlow) lie within the zone of $P$. nilsonni. In fact there is evidence to the contrary from the report of Das Gupta (1932, p. 351-2) who identified the graptolite species Monograptus vulgaris (= Pristiograptus ludensis), $M$. colonus var. ludensis ? ( $=P$. ludensis) and $M$. dubius $(=P$. dubius) from an horizon within the Lower Ludlow Shales 100 feet above the Wenlock Limestone at Millichope. One of us (J. H. S.) has determined Das Gupta's horizon to lie within the lithological transition from Lower to Middle Eltonian and immediately below beds with a $P$. nilssoni zone graptolitic assemblage. The Middle Elton Beds at Ludlow have yielded a similar P. nilssoni zone assemblage. (Holland, Lawson, and Walmsley, 1963, p. 107.)

This evidence leads us to believe that the Lower Elton Beds represent a dominantly shelly lateral equivalence of the uppermost $P$. ludensis zone as it occurs in the basin facies, and that the Wenlock/Ludlow boundary as defined by Holland, Lawson, and Walmsley lies within this zone. If, as Warren, Rickards, and Holland suggest, the base of the P. nilssoni zone is accepted as the base of the Ludlovian, we consider that the shales (Lower Elton Beds) immediately overlying the Wenlockian limestone facies should then be regarded as the highest division of the Wenlockian, in which conclusion we voice the opinions of Ketley (1865) and Davidson and Maw (1881).

\section{REFERENCES}

AleXander, F. E. S., 1936. The Aymestry Limestone of the Main Outcrop. Q. Jl geol. Soc. Lond., 92, 103-115.

Das GupTA, T., 1932. The Salopian graptolite shales of the Long Mountain and similar rocks of Wenlock Edge. Proc. Geol. Ass., 43, 325-363. 
Davidson, T., and G. MAw, 1881. Notes on the physical character and thickness of the Upper Silurian rocks of Shropshire, with the brachiopods they contain grouped in geological horizons. Geol. Mag., 18, 100-9.

Holland, C. H., J. D. Lawson, and V. G. Walmsley, 1963. The Silurian rocks of the Ludlow district, Shropshire. Bull. Br. Mus. nat. Hist. Geology, 8, No. 3, 93-171.

Ketley, C., 1865. On the Silurian rocks and fossils of Dudley. Rep. Br. Ass. Advmt Sc., 1865 (Birmingham), Trans. 63-65.

Warren, P. T., R. B. Rickards, and C. H. Holland, 1966. Pristiograptus ludensis (Murchison, 1839) and the position of the Wenlock/Ludlow boundary in the Silurian graptolite sequence. Geol. Mag., 103, 466-7.

Woon, E. M. R., 1900. The Lower Ludlow Formation and its Graptolite Fauna. Q. Jl geol. Soc. Lond., 56, 415-491.

\author{
M. G. BAsSETT, \\ DepartMent of Geology, \\ UNIVERSITY COLlEGE OF SWANSEA, \\ SINGLETON PARK, \\ SWANSEA.
}

13th March, 1967.

\author{
J. H. SHERGOLD, \\ Bureau of Mineral Resources, \\ GEOLOGY AND GEOPHYSICS, \\ POST OFFICE BOX 378, \\ CANBerra, \\ A.C.T., \\ Australla.
}

SIR,-Mr. Bassett and Dr. Shergold have found no evidence to suggest that the Lower Elton Beds of Wenlock Edge do not lie within the Zone of Pristiograptus nilssoni. Such evidence is at present confined to Das Gupta's (1932) report ; whilst, in our defence, it can be said that the Middle Elton Beds of the Ludlow district, with which Bassett and Shergold equate the Middle Elton Beds of Wenlock Edge, contain a graptolite fauna which in terms of the basin facies of Central and North Wales is of upper nilssoni Zone age. Furthermore, correlatives of the Lower Elton Beds in South Wales contain a lower nilssoni Zone graptolite fauna. Nor are the Lower Elton Beds of the Ludlow district entirely devoid of graptolites, though the material so far obtained is unpromising. Clearly, however, what is required is an accurate modern assessment of all such graptolite evidence as is available for the age of these beds in the Welsh Borderland, and this we are at present in the process of assembling.

Should the Lower Elton Beds prove to be of Pristiograptus ludensis age two alternatives are available. One is simply to accept that the Wenlockian/ Ludlovian boundary lies within the ludensis Zone, though rather high in that zone. The other is to make yet another change in the literature as suggested by your correspondents. The matter cannot be satisfactorily settled until our work on the graptolites is completed. If we can look forward, as does the recent Report of the Stratigraphical Code Sub-Committee of the Geological Society of London (Proc. geol. Soc. Lond. 1967, 1638, 75-87), to a time when standard Silurian stages are established on an international basis in the most suitable area, it may well be that the British sequence, heavily overprinted as it is with gross facies changes, may be superseded by a more appropriate one elsewhere. For the time being, our original letter tried to assist in problems of international correlation by suggesting that it might be most appropriate, in the graptolitic basinal facies, to take the base of the nilssoni Zone as the base of the Ludlovian. It was not our intention thus to redefine the base of the Ludlovian Series, as implied by Bassett and Shergold ; indeed we explicitly took the base as that taken by Holland et al. (1963), i.e. that taken by Alexander (1936). Rather, did we attempt to help those constructing correlation tables and making maps of the basinal facies to find an horizon most nearly coeval with the Wenlockian/Ludlovian boundary in the type area. We believe that they will not be so very far out in using the base of the $P$. nilssoni Zone in their correlation with the base of the Lower Elton Beds at 
Ludlow; certainly they will not be so far out as if they continued to use the base of the $P$. ludensis Zone as the base of the Ludlovian.

C. H. Holland,

R. B. RICKARDS,

Department of Geology,

Trinity College, DuBLIN, 2.

24th April, 1967.
P. T. WARREN,

Institute of Geological Sciences, Ring Road Halton, LEEDS, 15.

\section{IGNIMBRITE IN MALAYA}

SIR,- $-\mathrm{Mr}$. Aw is to be congratulated on his recognition of the Temangan dyke as an ignimbrite (Geol. Mag., 104 (1), 13-14), which is indeed the first published record of this rock type in Malaya, although the present writer has previously mapped ignimbrites (first identified by Flinter, personal communication) over some square miles in the south of the country, in Johore state. Unfortunately the bulletin on this area, written in 1962, still awaits publication (Burton, in manuscript). The Johore ignimbrites are of the welded tuff variety rather than the sillar kind found at Temangan.

Attention is drawn by Aw to an error on the 1963 geological map of Malaya (Alexander, 1965) wherein the Temangan dyke is represented as quartz porphyry. In fact other, more extensive, areas of quartz porphyry in this map are now similarly known to be of volcanic character. During reconnaissance mapping, officers of the Malayan Geological Survey used the term quartz porphyry in a purely descriptive sense to refer to rocks comprised of a fine matrix within which phenocrysts of feldspar are prominent. Although not made clear in the legend, it is this usage which has been perpetuated in the 1963 map. Owing to the intense tropical weathering of many exposures, particularly in low-lying areas in the states of Pahang and Johore, the true nature of these rocks long remained obscure. For some time it was believed that many of them were of metasomatic genesis, comprising recrystallized sediments bearing porphyroblasts of quartz, plus feldspar. Later it became evident to the writer that the quartz porphyries of the Rompin Forest Reserve in Pahang are volcanic in nature and that their large quartzes, which give the impression of "growing" in situ, are actually in various stages of corrosion. Some, at least, of these rocks are probably ignimbrites also. Geologists working in other areas in Malaya have arrived, independently, at similar conclusions and it is now realized that, like the Temangan dyke, many of the "intrusive quartz porphyries" shown in the 1963 map, particularly in Pehang and in Perak, are in reality rhyolitic and rhyodacitic volcanic rocks.

Aw considers that the Temangan ignimbrite plugs an old feeding fissure. It is significant that this feature has an almost rectilinear trace throughout its length of 15 miles and is generally within a few hundred yards of the boundary between Aw's "shales and sandstones" and his "Kelantan schists "-a boundary that MacDonald (in manuscript) has shown to be itself approximately straight for some 40 miles. MacDonald has further recorded evidence of faulting and the incidence of iron mineralization at several points along this line of contact between two sedimentary formations of vastly different metamorphic grade. To northward this line passes below an alluvial cover, but when projected to SSE it marks the eastern margin of the Boundary Range granite batholith for 38 miles and corresponds to a narrow zone of outcrop discontinuity for a further 30 miles, at least. At the same time it appears to control the adjacent long straight course of the Lebir river. Moreover, on the earlier 1948 geological map of Malaya (Ingham, 1948) an elongate development of volcanic rocks is indicated extending some 36 miles along the Lebir valley. Whilst much of this volcanic belt has been omitted from the 1963 map, the writer can vouch for the existence of some, at least, of the excluded volcanic rocks. Around Kuala Hawa these closely resemble the welded tuffs of Johore. 